DOI https://doi.org/10.30525/978-9934-26-038-4-50

\title{
ЗНАЧЕННЯ НЕПРЯМИХ МЕТОДІВ ДОСЛІДЖЕННЯ МІКРОБІОТИ ТОНКОГО КИШЕЧНИКА
}

\author{
Ткачук В. В. \\ кандидат медичних наук, \\ асистент кафедри сімейної медицини \\ Одеський національний медичний університет \\ Ткачук I. B. \\ асистент кафедри сімейної медицини \\ Одеський національний медичний університет \\ м. Одеса, Украӥна
}

Останніми роками велика увага науковців приділяється змінам стану мікробіоти кишечника. Причиною цього $є$ процеси, що відбуваються в результаті порушення мікробіоценозу кишечника, що можуть прямо або опосередковано впливати на моторику кишечника, змінювати характер метаболічних процесів, сприяючи розвитку імунного запалення в слизовій оболонці, що може лежати в основі патогенезу багатьох хронічних захворювань кишечника та інших органів [4, с. 246; 7, с. 2035].

Методи, які використовуються для дослідження мікробіоти кишечника, діляться на прямі та непрямі. Прямий метод полягає в посіві на середовища вмісту тонкого кишечника (дванадцятипалої або порожньої кишки), отриманого за допомогою стерильного зонда [1, с. 90]. Але цей метод має ряд недоліків [6, с. 1831]. Так, зокрема, він дає можливість визначити лише незначну частину мікроорганізмів, які знаходяться в зразках аспірату. Недоліком цього методу $є$ і тривалість дослідження (від 3-5 до 10 та більше днів).

Перспективними методами дослідження мікробіоти кишечника $є$ непрямі методи, до яких, наприклад, відносяться тести, основані на вивченні метаболітів мікрофлори: водневий дихальний тест з глюкозою або лактулозою [1, с. 90].

Існують також методи, які грунтуються на вивченні концентрації індикана, що виділяється індол-позитивними мікроорганізмами, фенолу і паракрезолу, що є метаболітами анаеробних (в основному), аеробних (рідше) мікроорганізмів, проте ці методи використовуються рідко [1, c. 91].

Існує спосіб діагностики стану мікробіоценозу різних біотопів, у тому числі кишечника, заснований на визначенні коротколанцюгових 
жирних кислот у тонкокишковому аспіраті (вони є метаболітами в основному анаеробних видів мікроорганізмів) методом газо-рідинного хроматографічного аналізу $[1$, с. 91]. Недолік цього дослідження - необхідність застосовувати складний метод газо-рідинної хроматографії.

Одним із непрямих методів дослідження мікробіоти тонкого кишечника є дослідження ступеня дисбіозу (СД) за А. П. Левицьким [3, с. 1]. Згідно цього методу, для оцінки мікробного обсіменіння тонкої кишки визначається активність ферменту уреази, яка не виробляється соматичними клітинами, але синтезується більшістю бактерій, які відносяться до умовно-патогенних і патогенних. Для розрахунку СД кишечнику необхідно лише визначити співвідношення відносних активностей уреази і лізоциму (показник неспецифічного антимікробного захисту).

Цей метод порівняно з класичним має переваги, оскільки відображає результат взаємодії макро- і мікроорганізмів, останній же враховує тільки кількісні зміни та співвідношення певних видів мікроорганізмів. Важлива перевага цього методу - простота, швидкість та об'єктивність, що робить його незамінним при масових дослідженнях [5, с. 16].

Тому 3 метою дослідження мікробіоти тонкого кишечника було проведено дослідження, в якому здійснювали відтворення стану дисбіозу, використовуючи модель, запропоновану А. П. Левицьким [2, с. 2]. Наступним етапом було дослідження мікробіоти тонкої кишки шляхом визначення СД ферментативним методом [3, с. 2].

Дослідження було проведено на 16 щурах лінії Вістар, які були розподілені на дві групи: контрольну та дослідну. Було встановлено, що у тварин, яким моделювали дисбіоз шляхом застосування лінкоміцину, спостерігалось збільшення активності уреази та зниження активності лізоциму i, як наслідок, достовірне збільшення СД (у 2,6 разів, $\mathrm{p}<0,05)$ порівняно з групою контролю.

Висновок. У зв'язку з недосконалістю методу бактеріологічного аналізу кишкового вмісту продовжуються пошуки альтернативних методів дослідження. Отримані дані дозволили встановити, що одним із таких досліджень може розглядатись визначення СД ферментативним методом, який має практичну цінність в діагностиці мікробної контамінації тонкої кишки.

\section{Література:}

1. Ардатская М. Д. Синдром избыточного бактериального ростав тонкой кишке: современные методы диагностики и подходы к лечебной коррекции. Медицинский совет. 2016. № 14. С. 88-95.

2. Спосіб моделювання дисбіозу (дисбактеріозу): пат. 31012 Україна: МПК (2006) А61Р31/00, № u200711609; заявл. 22.10.2007; опубл. 25.03.2008. Бюл. № 6.2 c. 
3. Спосіб оцінки ступеня дисбіозу (дисбактеріозу) органів і тканин: пат. 43140 Україна: МПК (2009) G01N33/48, № u200815092; заявл. 26.12.2008; опубл. 10.08.2009. Бюл. № 15. 2 с.

4. Степанов Ю. М., Федорова Н. С., Зигало Е. В. Ефективність рифаксиміну в корекції синдрому надлишкового бактеріального росту при хронічних запальних та функціональних захворюваннях кишечника. Гастроентерологія. 2019. № 53(4). С. 246-251.

5. Ферментативный метод определения дисбиоза полости рта для скрининга про- и пребиотиков: методические рекомендации / А. П. Левицкий и др.; Киев, 2007. 22 с.

6. Krajicek E. J., Hansel S. L. Small intestinal bacterial overgrowth: a primary care review. Mayo Clin. Proc. 2016, Dec. № 91 (12). P. 1828-1833.

7. Tilg H., Cani P. D., Mayer E. A. Gut microbiome and liver diseases. Gut. 2016. № 65. P. 2035-2044. 